INDEPENDENT JOURNAL OF MANAGEMENT \& PRODUCTION (IJM\&P)

\title{
AN ANALYSIS OF ACCIDENT TRENDS ANDMODELING OF SAFETY INDICES IN AN INDIAN CONSTRUCTION ORGANIZATION
}

\author{
Sunku Venkata Siva Rajaprasad \\ KL University, Vaddeswaram \& NICMAR, Hyderabad, India \\ E-mail: sunku.vsrp@gmail.com
}

\author{
P. Venkata Chalapathi \\ Mechanical Engineering Department, $K L$ University, India \\ E-mail: pvrao@kluniversity.in
}

Submission: $28 / 10 / 2015$ Accept: 20/02/2016

\section{ABSTRACT}

Construction industry has been recognized as a hazardous industry in many countries due to distinct nature of execution of works. The accident rate in construction sector is high all over the world due to dynamic nature of work activities. Occurrence of accidents and its severity in construction industry is several times higher than the manufacturing industries. The study was limited to a major construction organization in India to examine the trends in construction accidents for the period 2008-2014. In India, safety performance is gauged basing on safety indices; frequency, severity and incidence rates. It is not practicable to take decisions or to implement safety strategies on the basis of indices. The data used for this study was collected from a leading construction organization involved in execution of major construction activities all over India and abroad. The multiple regression method was adopted to model the pattern of safety indices wise. The pattern showed that significant relationships exist between the three safety indices and the related independent variables.

Keywords: Frequency rate, severity rate, incidence rate 


\section{INTRODUCTION}

Due to the high accident rates on construction sites internationally, strong health and safety legislation has been devised to minimize accidents and promote construction workers' safety. Construction work is one of the most well-known highrisk occupational areas in modern society and among the most hazardous, as measured by work-related mortality, injury rates, and workers' compensation payments (LARSON; POUSETTE;TORNER, 2008).

The difference in accident rates between developed and developing countries is remarkable. Proper accident recording and notification systems are non-existent in many developing countries (RAJAPRASAD; CHALAPATHI, 2014).

All stakeholders are responsible with the support of Government to improve accident rate in Malaysian construction industry and also framed action plan with recommended actions to minimize accidents. The action plan mainly focused on safety legislation\& enforcement, training, promotional activities and standards (ABDULLAH; GLORIA, 2010).

Accident causation theories have enhanced the awareness of causes of accidents and also emphasized on effect of human mistakes. The theories are failed to offer extensive strategic guidelines for line managers for reducing risks at construction sites (HOSSEINIAN; TORGHABEH, 2012). A study conducted in Kuwait construction industry suggested that accidents are primarily due to management practices rather than human errors, which is not having large effect (TABTABAl, 2002). Analysis of nature of fall accidents in construction sites in Indonesia revealed that worker behavior is contributing to fall injuries(LATIEF, et al., 2011).

Data pertaining to accident statistics of previous years is necessary to identify the causes of accidents in the construction sector as the findings would be more consistent than the results of a questionnaire survey. Efficient safety practices and mitigation measures may be initiated to eliminate and reduce reoccurrences in the future with aid of accurate statistical data relating to accidents. Actual status of construction safety and health issues could be ascertained by analyzing statistical data of accidents (CHONG; THUAN, 2014).

Lack of coordination and improper communication between management and employees are contributing factors of accidents (TEO;LING;CHONG,2005; LAUVER, 
DOI: $10.14807 /$ ijmp.v7i3.432

2007). Accident statistics relating to the construction industry manifest that the accident rate in Malaysian construction industry is high and require a major overhaul from the current site safety practices (HAMID; MAJID; BACHAN SINGH, 2008).

A study conducted in the USA indicated that the causes of accidents were due to lack of training and failure to adopt applicable legislations of safety (Toole, 2002). Accidents in the construction industry in China is mainly due to insufficient budget for safety; lack of enforcement of safety regulation and lack of organizational commitment (TAM; ZENG; DENG, 2004). Safety professionals generally develop safe practices adopted in similar construction sites and in addition to previous exposure, data pertaining to accidents is useful for conducting hazard identification and risk assessment process (GURCANLI; MUNGEN, 2013). A study was conducted in the thermal plant in India basing on the accident statistics and analyzed safety indices which are useful for continuous improvement (ABHAYNATH , 2015).

Safety performance has been monitored by safety metrics and these metrics are useful to make comparison with industry averages /other organizations. Analyzing safety metrics over a period of time is vital to identify the trends in construction industry (HINGE;THURMAN; WEHLE,2013). Regression analysis was applied to examine the injury rate in Malaysian manufacturing industries and the results show that there is negative relation between organization size and injury rate (SAAD; FATIMAH; ZAINIHAN, 2012).

A comprehensive standard was developed in India during 1983 regarding method for computation of frequency and severity rates for industrial injuries and classification of accidents. There is an ambiguity and no single safety indices will give actual status of safety but still in force. The reason being a serious accident has a considerable effect on the severity rate but it does not greatly affect the frequency rate. Many accidents and property damage not causing man days lost are not properly indicated by safety indices. It is also not good practice to compare two construction organizations based on their frequency and severity rates as type of hazards, working conditions, attitude of employees etc differ from organization. Severity rate does not represent actual pain and suffering of a worker .Low frequency rate does not mean that severity rate is also low that is one fatal accident is best example. 
DOI: 10.14807/ijmp.v7i3.432

Practically the safety indices are the partial indicators of injuries and no indices is capable of giving complete overview of safety performance. An attempt has been made in the present study to draw the trends of safety indices that are frequency, severity and incidence rates by using multiple regression.

\section{SAFETY INDICES}

To calculate safety indices it is required to collect data pertaining to total man hours worked, number of accidents, man days lost due to an accident and average number persons employed. In the present study, two more additional variables were also considered which influence safety performance; number near miss cases and allocation of safety budget.

\subsection{Man hours}

Man-hours worked shall be calculated from the pay roll or time clock recorded including overtime. When this is not feasible, the same shall be estimated by multiplying the total man-days worked for the period covered by the number of hours worked per day. The total number of man-days for a period is the sum of the number of men at work on each day of the period. If the daily hours vary from department to department separate estimates shall be made for each department and the result added together (IS, 1983).

\subsection{Frequency Rate (FR)}

Frequency rate indicate how often do injuries occur. It is calculated both for lost time injury and reportable lost time injury as follows:

$\mathrm{FR}=$ Number of lost time injury $\times 1000000 /$ Man-hours worked

Loss time injury is an injury causing disablement extending beyond the day of the shift on which the accident occurred (IS, 1983).

\subsection{Severity rate (SR)}

Severity rate indicate how serious are the injuries. It is calculated from man days lost both of lost time injury and reportable lost time injury as follows,

SR $=$ Man-days lost due to lost time injury $\times 1000000 /$ Man-hours worked 
DOI: 10.14807/ijmp.v7i3.432

Man-days lost according to schedule of charges for death and permanent disabilities as given in Appendix A. In case of multiple injury, the sum of schedule charges shall not be taken to exceed 6000 man-days (IS, 1983).

\subsection{Incidence Rate (IR)}

Incidence rate is the ratio of the number of injuries to the number of persons during the period under review (IS, 1983). It is expressed as the number of injuries per 1000 persons employed and it is calculated as follows,

$\mathrm{IR}=$ Number of lost-time injuries $\times 1000 /$ Average number of persons employed

\subsection{Safety budget}

Safety budget should emphasize the cost of prevention activities against cost of occurrences of safety related incidents. Managements still of the opinion that safety budget is cost to the business activity. Allocation of sufficient funds health and safety is essential to meet requirements of applicable legislations and to minimize the cost of accidents. In the Chinese construction sector, the cost of accidents accounts approximately $8.5 \%$ of the total tender price and in Kuwait it accounts $0.25-2 \%$ of project cost (GODWIN, 2011).

\subsection{Near Miss incident}

Near-miss incident may not injuries and damage to the property. All the near miss cases are to be reported, investigated and immediately rectified, as the near misses are indications of accidents in near future. Safety awareness programmes and trainings are useful tools to educate the employees in identifying work place hazards and near misses. Each near miss is lessons to safety department as it clearly expose inherent weaknesses in the system. Researchers have expressed different opinions whether near miss cases are leading or lagging indicator (TOELLNER,2001; MANUELE, 2009).

\section{METHODOLOGY}

The data used in the present study was collected from a major construction organization in India for the period 2008 - 2014. The organization under study involved in execution of major construction activities in both infrastructure and real estate segments in India and abroad. 
DOI: 10.14807/ijmp.v7i3.432

The trends of safety indices that are frequency, severity and incidence rates were then determined and plotted. The multiple regression method was used to determine the relationships between frequency rate and number of accidents, total man hours worked, number of near misses \& allocation of safety budget; severity rate and man days lost, total man hours worked, number of near misses \& allocation of safety budget; incidence rate and average number of employees employed, total man hours worked, number of near misses \& allocation of safety budget using the statistical package for the social sciences (SPSS).

\subsection{Modeling construction Accidents}

The multiple regression models were adopted to determine the relationship between three safety indices (frequency, severity and incidence rates) and relevant independent variables. The model derived from a study of road accident deaths in India (Aderamo, 2012).

\subsubsection{Model for frequency rate}

In present study, the model for frequency rate is shown in equation (1),

$$
F R=M H+N A+N M+B A+e
$$

Where, $\mathrm{FR}=$ Frequency rate, $\mathrm{MH}=$ Total man hours, $\mathrm{NA}=$ No of loss time accidents, $\mathrm{NM}=$ Number of near miss cases, $\mathrm{BA}=$ Budget allocated under safety, $\mathrm{e}$ $=$ an error term

\subsubsection{Model for severity rate}

The model severity rate is shown in equation (2),

$$
S R=M H+M L+N M+B A+e
$$

Where, $\mathrm{SR}=$ Severity rate, $\mathrm{MH}=$ Total man hours, $\mathrm{ML}=$ Man days lost, $\mathrm{NM}=$ Number of near miss cases, BA $=$ Budget allocated under safety, $\mathrm{e}=$ an error term

\subsubsection{Model for incidence rate}

The model for incidence rate is shown in equation (3),

$$
I R=N A+P E+N M+B A+e
$$


DOI: 10.14807/ijmp.v7i3.432

Where, $I R=$ Incidence rate,$P E=$ Average number of persons employed, $N A=$ Number of loss time accidents, $\mathrm{NM}=$ Number of near miss cases, $\mathrm{BA}=$ Budget allocated under safety, $\mathrm{e}=$ an error term.

The collected data were analyzed with the Statistical Package for the Social Sciences (SPSS).

\section{RESULTS}

\subsection{Trend in safety indices}

The data pertaining to safety performance of a construction organization in India is shown in Table 1 for the period $2008-2014$. Year wise safety indices are shown in Table 2.

Table 1: Statistics on accidents

\begin{tabular}{|c|c|c|c|c|c|c|}
\hline Year & $\begin{array}{c}\text { Man hours } \\
\text { (MH) }\end{array}$ & $\begin{array}{c}\text { No of } \\
\text { accidents } \\
\text { (NA) }\end{array}$ & $\begin{array}{c}\text { Man days } \\
\text { lost } \\
\text { (ML) }\end{array}$ & $\begin{array}{c}\text { Near } \\
\text { misses } \\
\text { (NM) }\end{array}$ & $\begin{array}{c}\text { Budget } \\
\text { allocated } \\
\text { (BA) }\end{array}$ & $\begin{array}{c}\text { Average no } \\
\text { of persons } \\
\text { employed }\end{array}$ \\
\hline 2008 & 3207879 & 21 & 124 & 54 & 1.60 & 764 \\
\hline 2009 & 4837980 & 17 & 12200 & 12 & 0.85 & 1152 \\
\hline 2010 & 2510798 & 10 & 6228 & 21 & 1.75 & 598 \\
\hline 2011 & 7174088 & 20 & 218 & 44 & 2.76 & 1708 \\
\hline 2012 & 3886768 & 27 & 12090 & 25 & 1.58 & 925 \\
\hline 2013 & 5897771 & 38 & 18116 & 9 & 2.44 & 1404 \\
\hline 2014 & 2633509 & 11 & 12040 & 23 & 2.20 & 628 \\
\hline
\end{tabular}

Table 2: Values of safety indices

\begin{tabular}{|c|c|c|c|}
\hline Year & Frequency rate (FR) & Severity rate (SR) & Incidence rate (IR) \\
\hline 2008 & 0.153 & 0.0260 & 27.49 \\
\hline 2009 & 0.285 & 0.0004 & 14.76 \\
\hline 2010 & 0.251 & 0.0040 & 16.72 \\
\hline 2011 & 0.358 & 0.0330 & 11.71 \\
\hline 2012 & 0.144 & 0.0003 & 29.19 \\
\hline 2013 & 0.155 & 0.0003 & 27.07 \\
\hline 2014 & 0.239 & 0.0002 & 17.54 \\
\hline
\end{tabular}

The trend in accidents basing frequency rate shows fluctuating with maximum value during 2011 and the trend relating severity rate reached almost zero for the period 2012 -2014 with maximum severity noticed during 2011 . On contrary to the two indices, the incidence rate is maximum during 2012 and minimum during 2011. The trends of frequency, severity and incidence rates are shown graphically in Figure 1,2 and 3 respectively. 
INDEPENDENT JOURNAL OF MANAGEMENT \& PRODUCTION (IJM\&P)

http://www.ijmp.jor.br

v. 7, n. 3, July - September 2016

ISSN: 2236-269X

DOI: 10.14807/ijmp.v7i3.432

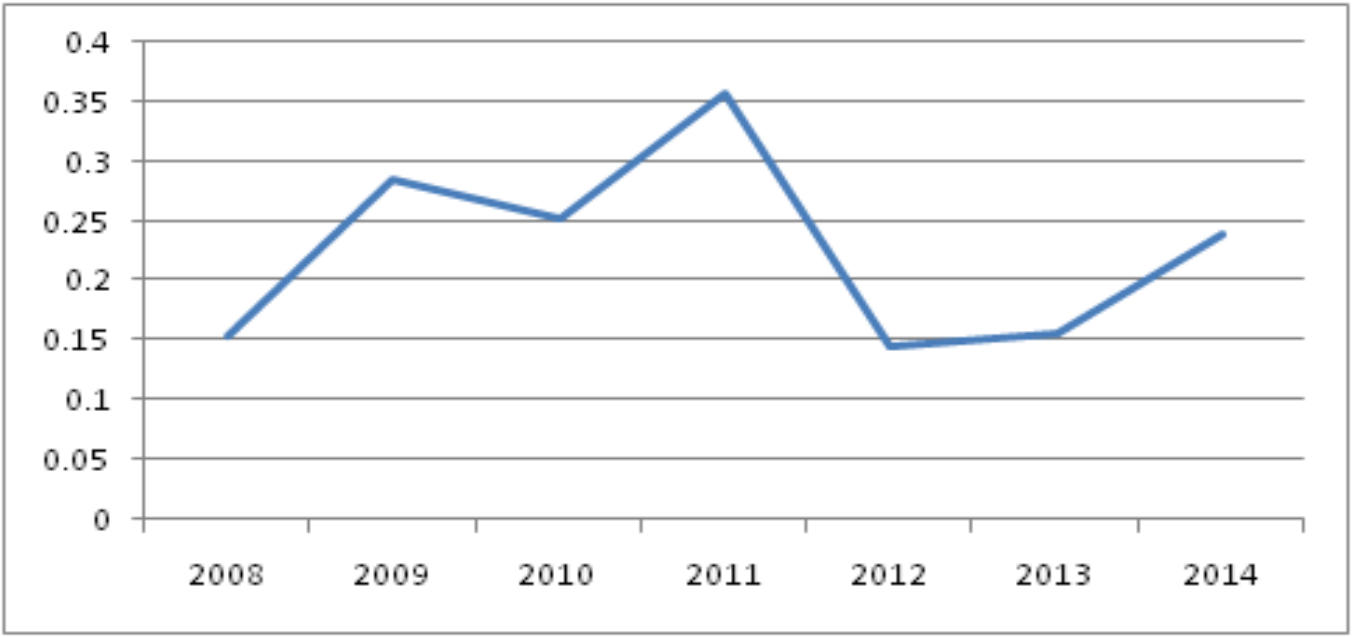

Figure 1: Trend in frequency rate

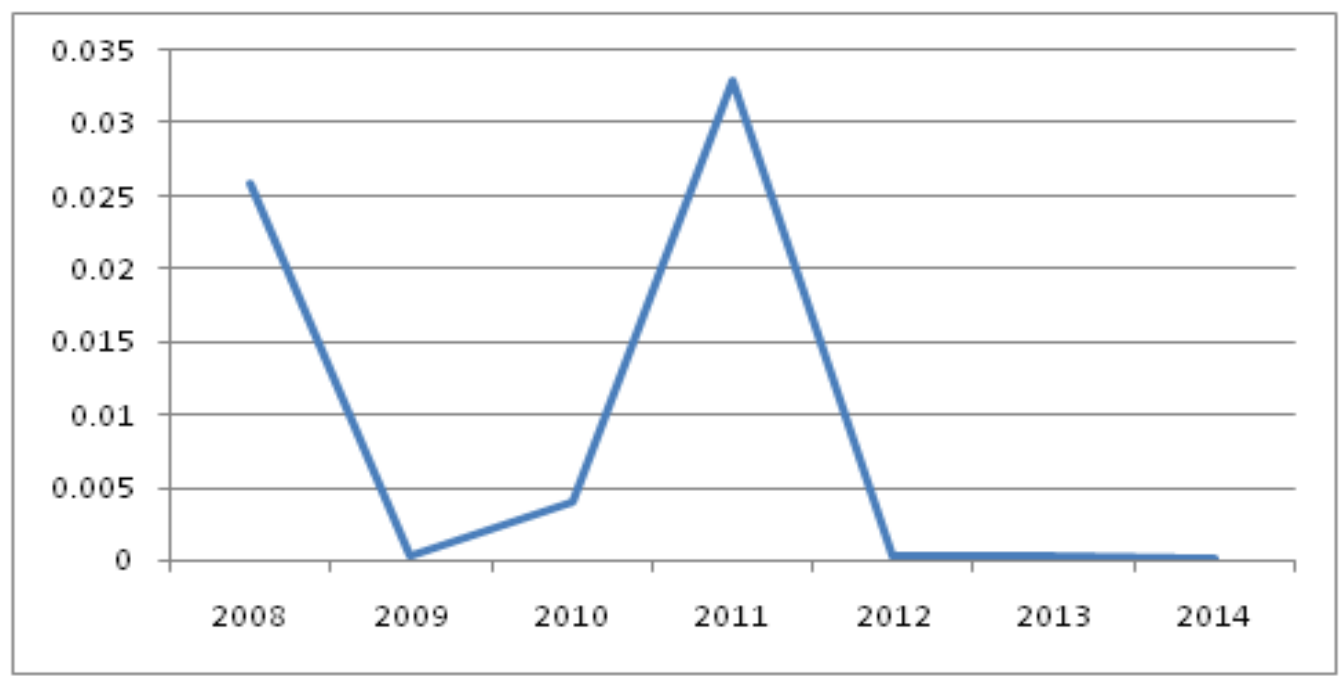

Figure 2:Trend in severity rate

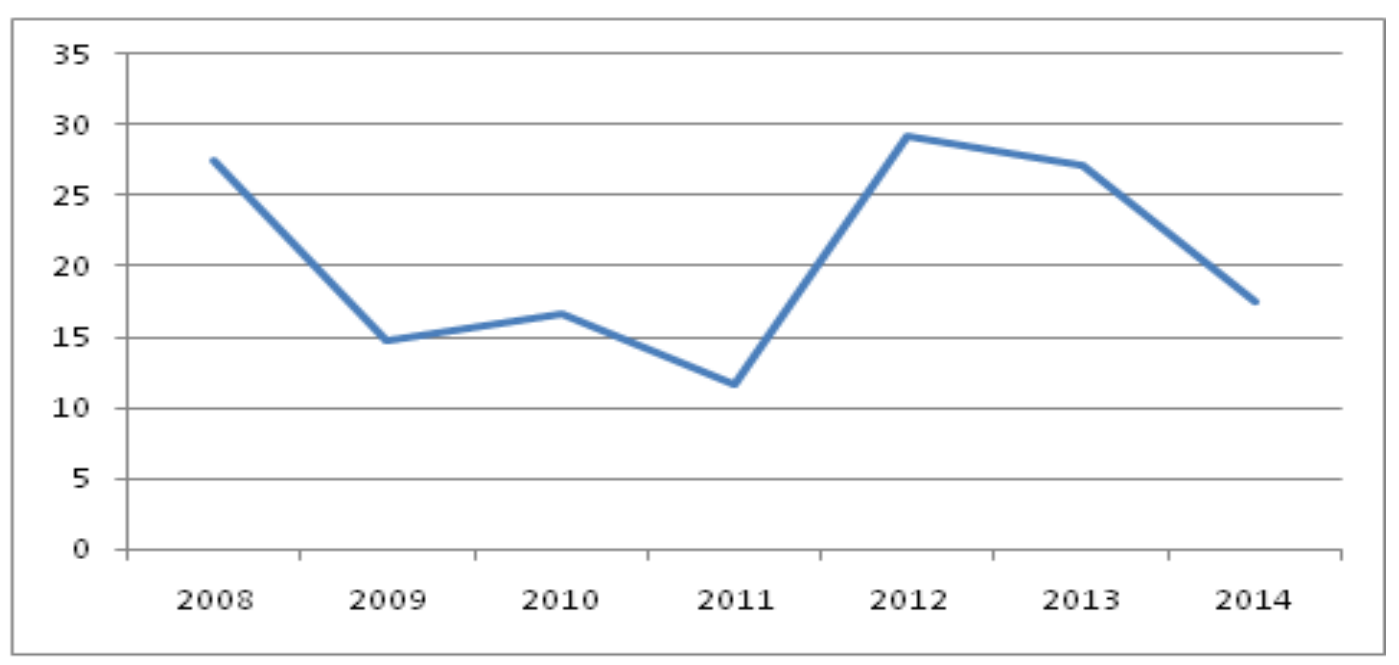

Figure 3: Trend in incidence rate 
DOI: 10.14807/ijmp.v7i3.432

\subsection{Model for frequency rate}

The model for frequency rate is shown in equation (1) and Table 3 shows the regression summary for frequency rate and the independent variables. The four independent variables explain $99.82 \%$ of the total variation infrequency rate. The remaining $0.18 \%$ is due to the variables which cannot be included in the model.

Table 3: Regression Summary for frequency rate ( ${ }^{*}$ Significant at $5.0 \%$ level)

\begin{tabular}{|c|c|c|c|c|c|}
\hline $\begin{array}{c}\text { Dependent } \\
\text { Variable }\end{array}$ & $\begin{array}{c}\text { Independent } \\
\text { Variables }\end{array}$ & $\begin{array}{c}\text { Regression } \\
\text { Coefficient }\end{array}$ & $\begin{array}{c}\text { Standard } \\
\text { Error }\end{array}$ & t-values & $\begin{array}{c}\text { Levels of } \\
\text { Significance }\end{array}$ \\
\hline \multirow{4}{*}{$\begin{array}{c}\text { Frequency } \\
\text { rate(FR) }\end{array}$} & Constant & 0.2244 & 0.0119 & 18.91 & 0.034 \\
\cline { 2 - 6 } & $\mathrm{MH}$ & $4.6 \mathrm{E}-08$ & $2.8 \mathrm{E}-09$ & $16.00^{*}$ & 0.039 \\
\cline { 2 - 6 } & $\mathrm{NA}$ & -0.0094 & 0.0005 & $-17.35^{*}$ & 0.037 \\
\cline { 2 - 6 } & $\mathrm{NM}$ & -0.0008 & 0.0004 & -1.757 & 0.329 \\
\cline { 2 - 6 } & $\mathrm{BA}$ & 0.0087 & 0.0068 & 1.284 & 0.421 \\
\hline
\end{tabular}

The regression summary shows that total man hours, number of accidents, number of near misses and budget allocation has positive association with frequency rate. Table 4 shows results of analysis of variance and the regression is significant since the F-statistic of 136.169 is greater than the critical value of 5.19 at 0.05 level of significance. The t-values also show that total man hours and number of loss time accidents are significant at 0.05 level. The coefficient of determination, $R^{2}$ which is $99.82 \%$ shows that the model is a good fit for the data. The predictive ability of the model is therefore confirmed.

The regression model obtained is,

$$
\mathrm{FR}=0.2244+4.6 \mathrm{E}-08 \mathrm{MH}-0.0094 \mathrm{NA}-0.0008 \mathrm{NM}+0.0087 \mathrm{BA}
$$

Table 4: Results of analysis of variance -Frequency rate

\begin{tabular}{|l|c|c|c|c|}
\hline $\begin{array}{c}\text { Source of } \\
\text { Variation }\end{array}$ & $\begin{array}{c}\text { Degrees of } \\
\text { freedom }\end{array}$ & Sum of Squares & Mean Square & F - value \\
\hline Regression & 4 & 0.0324 & 0.0081 & 136.169 \\
\hline Residual & 1 & $5.9 \mathrm{E}-05$ & $5.9 \mathrm{E}-05$ & \\
\hline Total & 5 & 0.0325 & & \\
\hline
\end{tabular}

\subsection{Model for severity rate}

The model for severity rate is shown in equation (2) and Table 5 shows the regression summary for severity rate and the independent variables. The four independent variables explain $99.73 \%$ of the total variation infrequency rate. The remaining $0.27 \%$ is due to variables which cannot be included in the model. 
Table 5: Regression Summary for severity rate ( ${ }^{*}$ Significant at 5.0\% level)

\begin{tabular}{|c|c|c|c|c|c|}
\hline $\begin{array}{c}\text { Dependent } \\
\text { Variable }\end{array}$ & $\begin{array}{c}\text { Independent } \\
\text { Variables }\end{array}$ & $\begin{array}{c}\text { Regression } \\
\text { Coefficient }\end{array}$ & $\begin{array}{c}\text { Standard } \\
\text { Error }\end{array}$ & t-values & $\begin{array}{c}\text { Levels of } \\
\text { Significance }\end{array}$ \\
\hline \multirow{3}{*}{$\begin{array}{c}\text { Severity } \\
\text { rate(FR) }\end{array}$} & Constant & -0.0037 & 0.0048 & -0.764 & 0.584 \\
\cline { 2 - 6 } & $\mathrm{MH}$ & $3.07 \mathrm{E}-09$ & $4.1 \mathrm{E}-10$ & $7.464^{*}$ & 0.084 \\
\cline { 2 - 6 } & $\mathrm{ML}$ & $-1.29 \mathrm{E}-06$ & $2.5-07$ & $-5.190^{*}$ & 0.121 \\
\cline { 2 - 6 } & $\mathrm{NM}$ & 0.0001 & 0.0001 & 0.860 & 0.547 \\
\cline { 2 - 6 } & $\mathrm{BA}$ & 0.0035 & 0.0013 & $2.588^{*}$ & 0.234 \\
\hline
\end{tabular}

The regression summary shows that total man hours, man days lost number of near misses and budget allocation has positive association with severity rate. Table 6 shows results of analysis of variance and the regression is significant since the Fstatistic of 91.765 is greater than the critical value of 5.19 at 0.05 level of significance. The t-values also show that total man hours man days lost and budget allocated are significant at 0.05 level. The coefficient of determination, R2 which is $99.73 \%$ shows that the model is a good fit for the data. The predictive ability of the model is therefore confirmed.

Table 6: Results of analysis of variance - Severity rate

\begin{tabular}{|l|c|r|r|r|}
\hline \multicolumn{1}{|c|}{$\begin{array}{c}\text { Source of } \\
\text { Variation }\end{array}$} & $\begin{array}{c}\text { Degrees of } \\
\text { freedom }\end{array}$ & Sum of Squares & Mean Square & F - value \\
\hline Regression & 4 & 0.0009 & 0.0002 & 91.765 \\
\hline Residual & 1 & $2.3 \mathrm{E}-06$ & $2.3 \mathrm{E}-06$ & \\
\hline Total & 5 & 0.0009 & & \\
\hline
\end{tabular}

The regression model obtained is,

$$
\mathrm{SR}=-0.0037+3.07 \mathrm{E}-09 \mathrm{MH}-1.29 \mathrm{E}-06 \mathrm{ML}+0.0001 \mathrm{NM}+0.0035 \mathrm{BA}
$$

\subsection{Model for incidence rate}

The model for incidence rate is shown in equation (3) and the Table 7 shows the regression summary for incidence rate and the independent variables. The four independent variables explain $99.88 \%$ of the total variation in incidence rate. The remaining $0.12 \%$ is due to variables which cannot be included in the model.

Table 7: Regression Summary for incidence rate ( ${ }^{*}$ Significant at 5.0\% level)

\begin{tabular}{|l|c|r|r|c|c|}
\hline $\begin{array}{c}\text { Dependent } \\
\text { Variable }\end{array}$ & $\begin{array}{c}\text { Independent } \\
\text { Variables }\end{array}$ & $\begin{array}{c}\text { Regression } \\
\text { Coefficient }\end{array}$ & $\begin{array}{c}\text { Standard } \\
\text { Error }\end{array}$ & t-values & $\begin{array}{c}\text { Levels of } \\
\text { Significance }\end{array}$ \\
\hline \multirow{3}{*}{$\begin{array}{l}\text { Incidence } \\
\text { rate(FR) }\end{array}$} & Constant & 16.035 & 0.833 & 19.243 & 0.033 \\
\cline { 2 - 6 } & $\mathrm{MH}$ & 0.949 & 0.038 & $25.013^{*}$ & 0.025 \\
\cline { 2 - 6 } & $\mathrm{PE}$ & -0.016 & 0.001 & $-18.808^{*}$ & 0.033 \\
\cline { 2 - 6 } & $\mathrm{NM}$ & 0.204 & 0.031 & $6.528^{*}$ & 0.096 \\
\cline { 2 - 6 } & $\mathrm{BA}$ & -1.784 & 0.475 & $-3.758^{*}$ & 0.165 \\
\hline
\end{tabular}


DOI: 10.14807/ijmp.v7i3.432

The regression summary shows that number of loss time accidents, average number of persons employed, number of near misses and budget allocation have positive association with severity rate. Table 8 shows results of analysis of variance and the regression is significant since the F-statistic of 209.234 is greater than the critical value of 5.19 at 0.05 level of significance. The coefficient of determination, R2 which is $99.88 \%$ shows that the model is a good fit for the data. The predictive ability of the model is therefore confirmed.

Table 8: Results of analysis of variance - Incidence rate

\begin{tabular}{|l|c|r|r|r|}
\hline \multicolumn{1}{|c|}{$\begin{array}{c}\text { Source of } \\
\text { Variation }\end{array}$} & $\begin{array}{c}\text { Degrees of } \\
\text { freedom }\end{array}$ & $\begin{array}{c}\text { Sum of } \\
\text { Squares }\end{array}$ & Mean Square & F - value \\
\hline Regression & 4 & 245.629 & 61.407 & 209.234 \\
\hline Residual & 1 & 0.293 & 0.293 & \\
\hline Total & 5 & 245.922 & & \\
\hline
\end{tabular}

The regression model obtained is,

$$
S R=16.035+0.949 N A-0.016 P E+0.204 N M-1.784 B A
$$

\section{CONCLUSION}

The analysis shows the trends in safety indices in an Indian construction organization. The trends in terms of frequency rate, severity rate and incidence rate for the period 2008 - 2014 have been examined. The trends of safety indices are distinct and all the indices shall be given equal importance while evaluating safety performance.

Implementing safety systems and strategic decisions relating to safety shall be based on examining the three safety indices. The reason for including near miss and safety budget as a variables in regression models is mainly due to their contribution towards safety performance. Conducting hazard identification and risk assessment for all construction activities, imparting safety training to all cadres of employees, developing safety culture as a part of organization culture and implementing motivational schemes are the drivers to improve safety indices.

Limitation of the study being exclusion of cost of accident damages in the regression models. It is very difficult to generalize cost of an accident, which comprise two cost components: direct and indirect cost. There is no relationship between direct and indirect costs but indirect cost is several times more than the direct cost. The cost of damages is accident specific. 
DOI: 10.14807/ijmp.v7i3.432

\section{REFERENCES}

ABHAYNATHh, K.; JAIN, N. K.; PRAVEEN, P. (2015) Analysis of Safety Performance Rating in Thermal Power Plant. International Journal of Emerging Technology and Advanced Engineering, v. 5, n. 1,p. 120-128.

ADERAMO, A. J. (2012) Spatial Pattern of Road Accident Casualties in Nigeria, Mediterranean Journal of Social Sciences, v. 3, n. 2,p. 61-72.

DAYANG, N. M. A. A.; GLORIA, C. M. W. (2011) An Analysis of Accidents Statistics in Malaysian Construction Sector. International Conference on E- business, Management and Economics, Hong Kong.

EMRE, G.; MUNGEN, U. (2013) Analysis of Construction Accidents in Turkey and Responsible Parties. Industrial Health, v. 51, n. 1,p. 581-595.

GODWIN, I. I. (2011) Effect of Mechanisation on Occupational Health and Safety Performance in the Nigerian construction industry. Journal of Construction in Developing Countries, v. 16, n. 2, p.27-45.

HAMID, A. R. A.; MUHD, Z. A. M.; BACHAN, S. (2008) Causes of Accidents at Construction Sites. Malaysian Journal of Civil Engineering, v. 20, n. 2, p. 242 259.

HASHREM, M. T. (2002) Analyzing Construction site accidents in Kuwait. Kuwait Journal of science and Engineering, v. 29, n. 2, p. 213- 238.

HEAP, Y. C.; THUAN, S. L. (2014) Accidents in Malaysian Construction Industry: Statistical Data and Court Cases. International Journal of Occupational Safety and Ergonomics, v. 20, n. 3, p. 503-513.

INDIAN STANDARD:3786 (1983) Method for Computation of Frequency and Severity rates for Industrial Injuries and Classification of Industrial Accidents, p. 1-28.

JIMMIE, H.; SAMUEL, T.; ANDREW, W. (2013) Leading Indicators of construction safety performance. Safety Science, v. 51, n. 2, p. 23-28.

LARSSON, S.; POUSETTE, A.; TORNER, M. (2008) Psychological climate and safety in the construction industry- mediated influence on safety behaviour. Safety Science, v. 46, n. 1, p. 405- 412.

LAUVER, K. J. (2007) Human resource safety practices and employee njuries. Journal of Managerial Issues, v.19, n. 3, p.397-413.

MANUELE, F. (2009) Leading and lagging indicators.Professional Safety, v. 54, n. 12, p. 28-33.

RAJAPRASAD, S. V. S.; VENKATA CHALAPATHI, P. (2014) Analysis of safety Performance in State and Sector Wise in India by Using TOPSIS. Research Journal of Applied Sciences, Engineering and Technology, v. 7, n. 21, p. 45414546.

SAAD, M. S.; FATIMAH, S.; ZAIRIHAN, H. (2012) The determinants of industrial Accidents in the Malaysian manufacturing sector, African Journal of Business Management, v. 6, n. 5, p. 1999-2006. 
SEYYED, S. H.; ZAHRA, J. T. (2012) Major Theories of Construction Accident Casuation Models: A Literature Review. International Journal of Advances in Engineering \& Technology, v. 4, n. 2, p. 53-66.

TAM, C. M.; ZENG, S. X.; DENG, Z. M. (2004) Identifying elements of poor construction safety management in China, Safety Science, v. 42, n. 2, p. 569-586.

TEO, E.; LING, F.; CHONG, A. (2005) Framework for project managers to manage construction safety. International Journal of Project Management, v. 23, n. 4, p. 329-41.

TOELLNER, J. (2001) Improving safety and health performance. Identifying and measuring leading indicators. Professional Safety, v. 46, n. 9, p. 42-47.

TOOLE, T. M. (2002) Construction Site Safety Roles. Journal of Construction Engineering and Management, v. 12, n. 3, p. 203-210.

YUSUF, L.; AKHMAD, S.; YULIANTO, S. N.; ROSMARIANI, A. (2011) The Nature of Fall Accidents in Construction Projects: A Case of Indonesia. International Journal of Civil \& Environmental Engineering, v. 11, n. 5, p. 80-84. 